Ann. Biol. anim. Bioch. Biophys., 1979, 19 (6), 1745-1756.

\title{
Evolution of ovarian follicular population and serum gonadotrophins in the prepubertal period of two strains of rats
}

\author{
par Marie-Madeleine de REVIERS, P. MAULÉON \\ Station de Physiologie de la Reproduction, I. N. R. A., \\ Nouzilly 37380 Monnaie.
}

Summary. A quantitative histological analysis of the growing follicle population was made in ovaries of two strains of Wistar rats $(03$ and 12$)$ during the prepubertal period ( 8 to 32 days after birth). The two strains have different sensitivities to exogenous FSH during this period $(03>12)$.

The analysis shows firstly an increase in the total number of follicles ( 8 to 20 days) followed by a decrease ( 20 to 32 days). This decrease is the result not only of atresia but also of a smaller number of follicles beginning to grow.

In strain 12 rats the total number and the size of follicles are less than in strain 03 , at 12 and 20 days after birth but very similar in the two strains at day 32.

The plasma LH concentrations measured between 8 and 32 days $p$. n. are not different between the two strains but are highly variable. The plasma FSH concentrations are high from day 8 to day 20 and low from 24 to 32 . These concentrations are significantly higher in rats of strain 12 .

This is a surprising finding since FSH is known to stimulate follicular growth and, despite the high concentrations, the follicular population is poorly developed in strain 12 .

A lack of development of FSH receptors in strain 12 rats at the early stage of follicular growth seems to be the more plausible hypothesis.

Although it has been known for some time that the first growing follicles in the rat appear after 3 days of age (Beaumont and Mandl, 1962), the subsequent evolution and establishment of the follicular population during the prepubertal period is poorly understood. Lane (1935) studied the follicular population between 15 and 66 days of age but divided the whole follicular population into only two broad categories, primary and vesicular follicles. Other workers have studied folliculogenesis in the same period but have only considered the antral follicles (Umezu, 1970 ; Meijs-Roelofs et al., 1973).

The present study was undertaken to determine the evolution of the population of growing follicles during the immature period.

Furthermore since several authors have now claimed that the early stages of follicle growth are gonadotrophin dependent (Ryle, 1972 ; de Reviers and Mauléon, 
1973 ; Lintern-Moore, 1977) it was considered to be of interest to measure gonadotrophin levels during the immature period. Two strains of rats which differ in their response to exogenous gonadotrophin were studied and the hormonal and follicular parameters were related at critical moments during the evolution of the follicular population.

Preliminary results of this work have been already presented (de Reviers and Terqui, 1976).

\section{Materials and methods.}

a) Animals. - Female rats of Wistar 03 and 12 strains (INRA) have been selected according to their ovarian response (ovarian weight) to exogenous FSH with strain 12 being less sensitive to this hormone. During the breeding and perinatal periods all animals were maintained under the same environmental conditions to reduce intra-strain herelogeneity (constant photoperiod of $14 \mathrm{~h}$ light and $10 \mathrm{~h}$ dark ; constant temperature $21 \pm 1{ }^{\circ} \mathrm{C}$; weaned at 23 days of age ; and fed the same ration).

b) The follicular populations. - After slaughter, the two ovaries were dissected out, fixed in Bouin-Hollande's solution, embedded in paraffin and cut serially at a thickness of $10 \mu \mathrm{m}$. All sections were then mounted, stained with Masson's trichrome and inspected microscopically.

(i) Comparison of different systems of follicle classification.

In order to determine the optimum method of classifying follicles an attempt was made to compare 4 of the more frequently used methods by measuring and classifying follicles of one ovary, according to each method (fig. 1).

These methods involve measuring the number of layers of granulosa cells (Mandl and Zuckerman, 1950), the number of granulosa cells (Pedersen and Peters, 1968), the follicle diameter (Paesi, 1949) or the surface area (Mauléon and Rao, 1963) of the largest cross-section of the follicle i.e. the section containing the nucleolus of the oocyte's nucleus.

The arrows indicate the same follicle measured according to the different methods, for example the solid arrow represents a follicle with a mean surface area between 5012 and $6310 \mu \mathrm{m}^{2}$ (Mauléon and Rao, 1963), mean diameter between 83 and $92 \mu \mathrm{m}$ (Paesi, 1949), with between 58 and 104 granulosa cells (type $3 b$ to $5 a$ of Pedersen and Peters, 1968) and the cells are arranged in 2-4 layers (Mandl and Zuckerman, 1950). The open arrow indicates a follicle in the class $63100-79940 \mu \mathrm{m}^{2}$, mean diameter 290-300 $\mu \mathrm{m}$, more than 600 cells and with more than 4 layers of granulosa cells.

It seems to us that the more precise ans discriminating measure is the area of the follicle. The measurement of mean follicle diameter is considered as precise as the area of the follicle however its presentation on a logarithmic scale would make handling of the data easier than the arithmetic scale of Paesi (1949). The criterion proposed by Mandl and Zuckerman (1950) and Pedersen and Peters (1968) do not take into account the spaces between the cells. Such spaces could change throughout the development of the follicle as they are formed by secretion from the cells and so are probably an important facet of follicle development. 
In this paper we shall use the following terms: small pre-antral follicles ( 1259 to $5012 \mu \mathrm{m}^{2}$ ), large pre-antral follicles (5012 to $50120 \mu \mathrm{m}^{2}$ ) and antral follicles (> $\left.50120 \mu \mathrm{m}^{2}\right)$. In Pedersen and Peter's (1968) classification, the term small follicles ( $\leqslant 20$ cells) included mostly non-growing follicles whereas our use of the term is only of growing follicles.
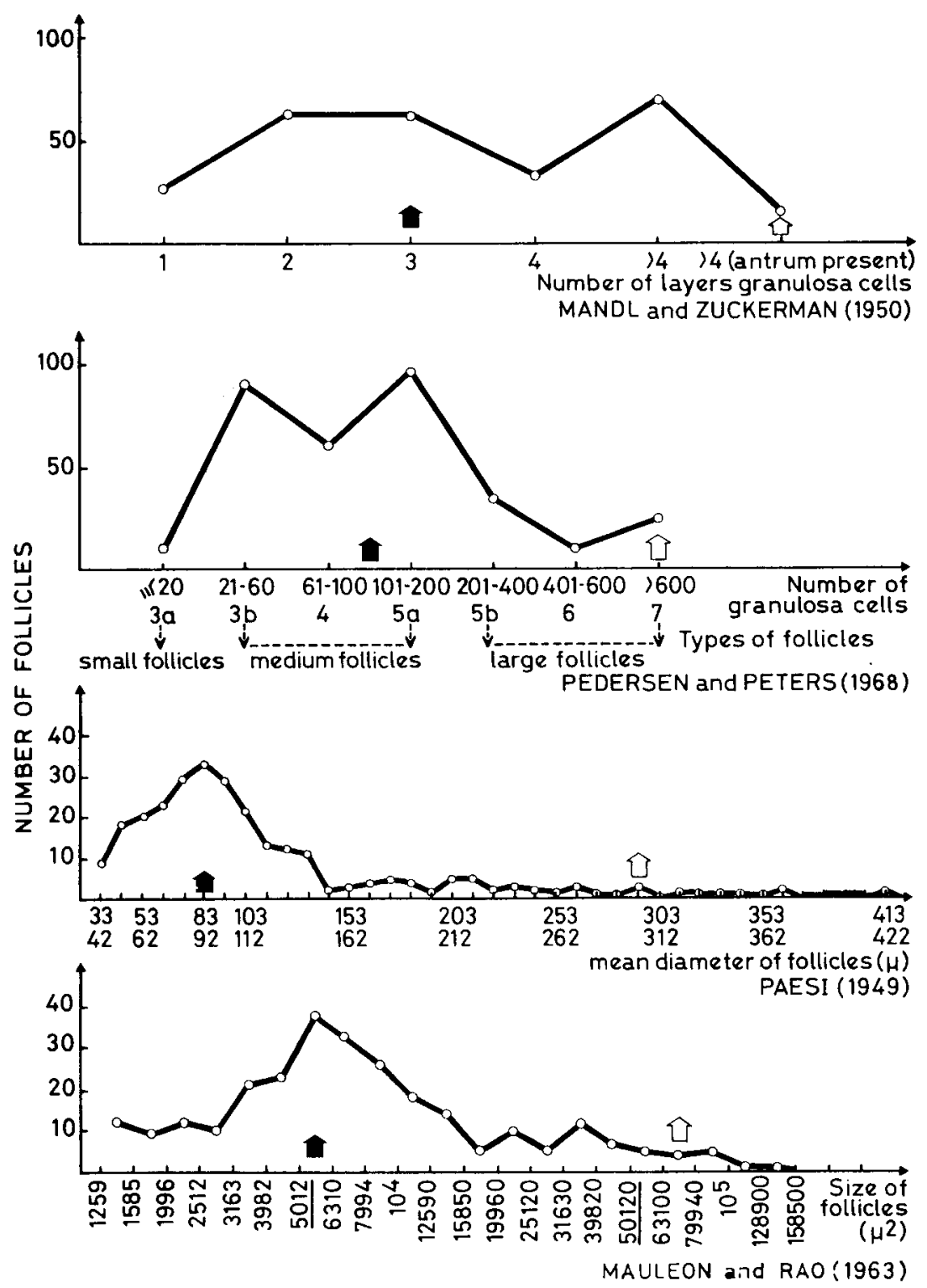

FIG. 1. - Comparative study of one rat ovary using four different methods of follicular classificution. The arrows represent the same follicle class according to each of the four methods. 
(ii) Populations of normal follicles.

The population of normal growing follicles was determined in two ovaries chosen from two different animals at each of the following times : strain $\mathrm{O} 3$ rats-8, 12, 16, 20, 24,28 and 32 days, and strain 12 rats-12, 20 and 32 days after birth.

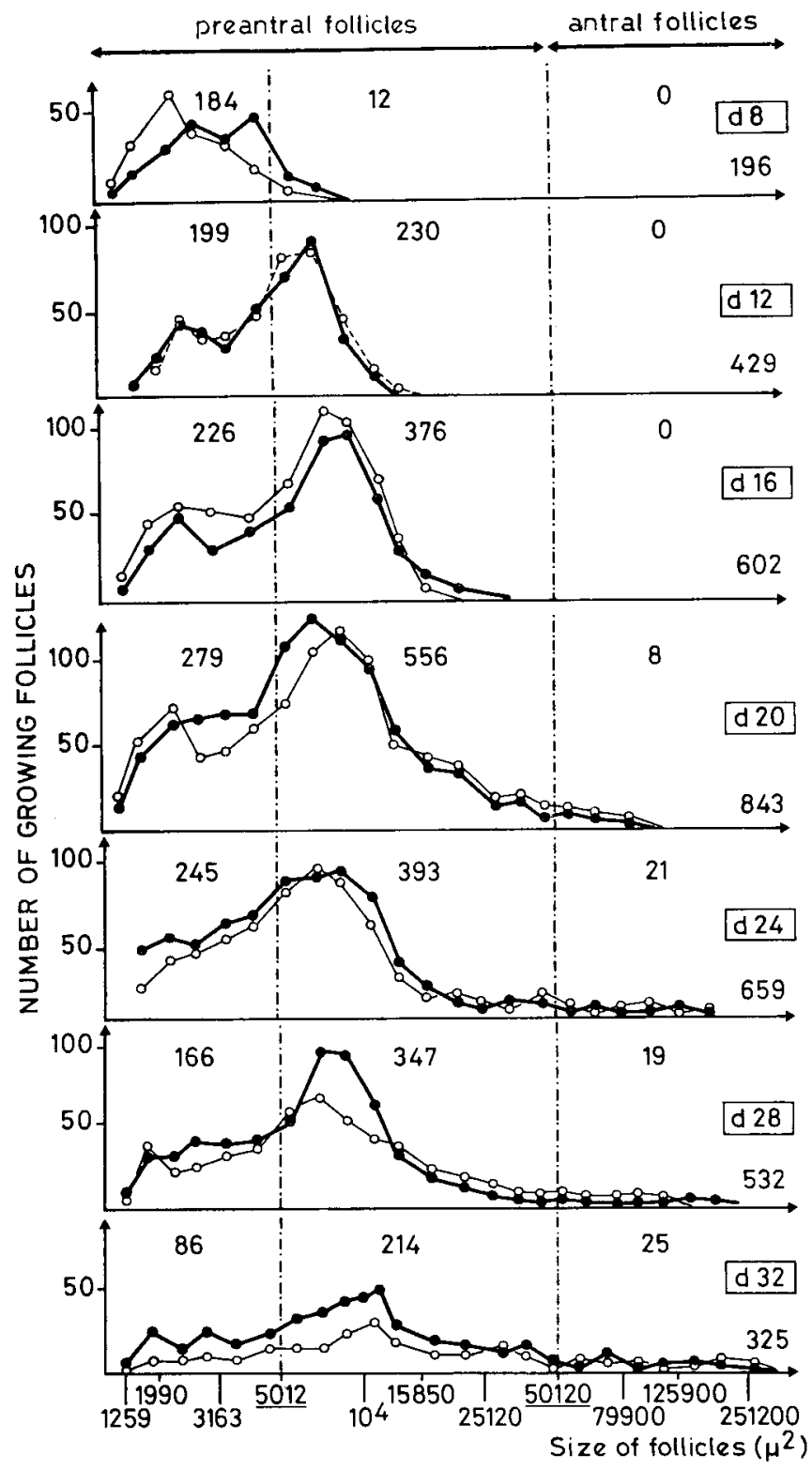

FIG. 2. - Changes in the ovarian follicular population with age in 03 strains. For each age studied between days 8 to $32(\square)$ the frequency curves of two different animals are shown. The total mean number of follicles per ovary, per age and the mean number per category per age are shown. 
(iii) Atretic follicles.

A follicle was considered atretic when more than 10 pycnotic bodies were found among the granulosa cells of the largest cross-section of the follicle. Measuring atretic follicles is difficult as atresia mainly affects the larger follicles $\left(>10^{4} \mu \mathrm{m}^{2}\right)$ and the structure of such follicles is partly destroyed. However an overall estimation of atresia was made from the relative volumes occupied by normal versus atretic follicles with respect to the inter-follicular tissue, a measurement used by Chalkley (1943). This method uses a 5-point micrometer and the number of times when the ends of the branch of the micrometer fall on different tissue (normal or atretic follicles or interfollicular tissue) was counted. This measurement was made on at least five different microscope fields of every fifth section.

c) FSH and LH plasma concentrations. - The plasma concentrations of FSH and LH were determined every two days between 8 and 20 days of age and every four days between 20 and 32 days of age for both strains of rats. The animals were decapitated between 10 and $11 \mathrm{a} . \mathrm{m}$. and blood collected in heparinized tubes.

Radioimmunoassays of FSH and LH were carried out using the methods and reagents of the NIAMD kits. Plasma samples were assayed in duplicate using 20 and $50 \mu \mathrm{l}$ samples for the FSH and $\mathrm{LH}$ assays respectively. Plasma values are expressed in $\mathrm{ng}$ FSH-R-P1 (2.1 $\times$ NIH-FSH-S1) and LH-R-P1 (0,03 $\times$ NIH-LH-S1) per $\mathrm{ml}$ of plasma. The sensitivities of the assays were 6.25 and $0.39 \mathrm{ng}$ of FSH and $\mathrm{LH}$ respectively. All plasma samples were measured in one assay to avoid between assay variation.

\section{Results.}

The evolution of the population of growing follicles in strain 03 rats.

(i) Normal follicles. - The frequency curves according to follicular size for strain O3 rats of different ages show that the total number of growing follicles increased between 8 and 20 days of age (196 to 843 follicles) and thereafter decreased to 325 at 32 days of age (fig. 2). The size of the largest follicle increased progressively and the

\section{TABLE 1}

The relative volume (p. 100) of normal and atretic follicles with respect to interfollicular tissue, in ovaries of two strains of rats between 8 and 32 days of age

\begin{tabular}{|c|c|c|c|c|c|c|}
\hline \multirow{2}{*}{$\begin{array}{l}\text { Age } \\
\text { (days) }\end{array}$} & \multicolumn{3}{|c|}{03 Strain } & \multicolumn{3}{|c|}{12 Strain } \\
\hline & $\begin{array}{l}\text { Normal } \\
\text { follicles }\end{array}$ & $\begin{array}{l}\text { Atretic } \\
\text { follicles }\end{array}$ & $\begin{array}{c}\text { Interfollicular } \\
\text { tissue }\end{array}$ & $\begin{array}{l}\text { Normal } \\
\text { follicles }\end{array}$ & $\begin{array}{r}\text { Atretic } \\
\text { follicles }\end{array}$ & $\begin{array}{l}\text { Interfollicular } \\
\text { tissue }\end{array}$ \\
\hline $\begin{array}{r}8 \\
12 \\
16 \\
20 \\
24 \\
28 \\
32\end{array}$ & $\begin{array}{l}38.7 \\
31.6 \\
35.2 \\
31.8 \\
21.3 \\
24.8 \\
28.7\end{array}$ & $\begin{array}{r}1.7 \\
4.8 \\
1.6 \\
9.7 \\
27.2 \\
25.6 \\
27.5\end{array}$ & $\begin{array}{l}59.7 \\
63.5 \\
63.1 \\
58.4 \\
51.3 \\
49.4 \\
43.7\end{array}$ & $\begin{array}{l}-\overline{43.4} \\
26.7 \\
27.0 \\
20.2 \\
19.5 \\
13.9\end{array}$ & $\begin{array}{l}- \\
0 \\
0.5 \\
7.8 \\
35.0 \\
22.8 \\
26.5\end{array}$ & $\begin{array}{c}- \\
56.4 \\
72.7 \\
65.1 \\
44.6 \\
57.5 \\
59.5\end{array}$ \\
\hline
\end{tabular}


largest follicles were found when the animals reached puberty which occurs at 3238 days of age. The more striking features of the frequency curves are :

- an increase in the small and large pre-antral follicles between 8 and 20 days of age ;

- the appearance of antral follicles at 20 days of age. The number of these follicles remained constantly low ;

- and the decrease in the number of small and large pre-antral follicles after day 20, demonstrating an important change in the follicular population at this time.

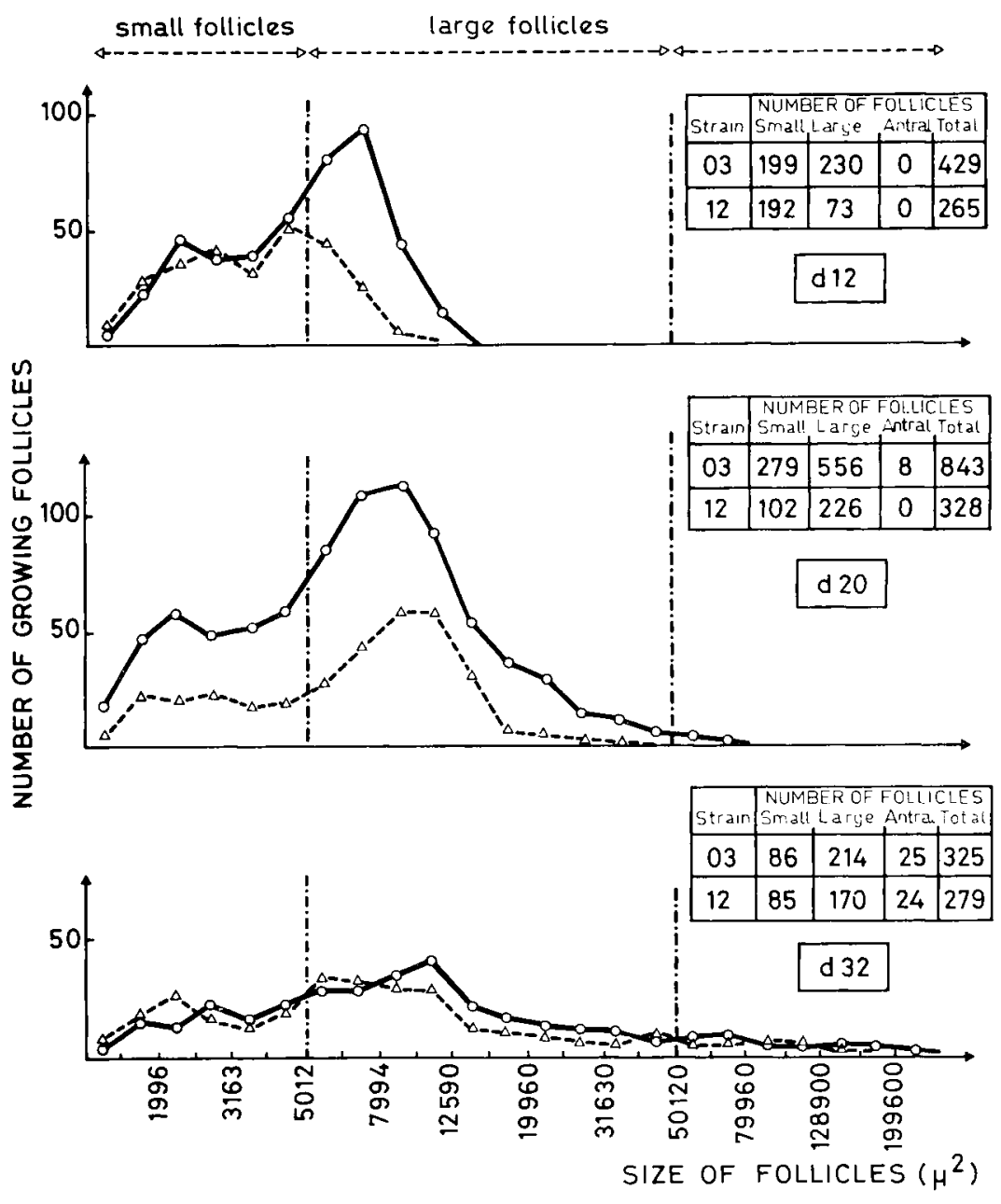

FIG. 3. - Comporison between the ovarian follicular population of two strains of rats (strains O3-Oand 12-- ---$)$ at 12, 20 and 32 days of age. The mean number of follicles of different strains is shown in the tables (mean of two ovaries). 
(ii) Atresia. - The relative volume of atretic follicles was low prior to 20 days of age but thereafter it increased to and remained at a similar level as that of the normal follicles during the prepubertal period (table 1). Thus also at 20 days of age there is a significant change in the level of atresia.

Follicular populations in rats of strains 03 and 12.

(i) Normal follicles. - The frequency curves, according to follicular size from the ovaries of rats of strains $O 3$ and 12 were determined at 12, 20 and 32 days of a ge (fig. 3). These ages represent important phases in the evolution of the follicular population of $\mathrm{O} 3$ strain rats, namely the increase, peak and decrease in the number of growing follicles.

The general profiles of the frequency curves were similar in the two strains with the following differences:

- there were more growing follicles in ovaries from strain $\mathrm{O} 3$ than from strain 12 rats at 12 and 20 days of age (respectively 160 and 260 p. 100) but there was little difference at day 32 of age, and

- in strain 12 rats antral follicles were not found at 20 days of age. Previous work has shown antral follicles present in strain 12 at 24 days of age (de Reviers, unpublished data).

(ii) Atresia. - The estimation of atresia was determined in both strains at ages of four days interval during the prepubertal period (table 1).

Atresia was similar in both strains with a marked increase at 24 days of age However, the relative volume of normal follicles of strain 12 rats did decrease from. days 12 to 32 (table 1 ).

FSH and LH concentrations in rats of strains 03 and 12.

(i) FSH plasma concentrations. - FSH plasma concentrations (fig. 4) were high between days 8 and 18 of age, decreased between days 20-24 of age and remained low

TABLE 2

Mean LH plasma concentrations ( \pm s. e. $\mathrm{m}$.) and coefficients of variation in immature female rats (strain 03 and 12) (ng LH RP1 per $\mathrm{ml}$ )

\begin{tabular}{rrrrrrr}
\hline $\begin{array}{c}\text { Age } \\
\text { (days) }\end{array}$ & Strain 03 & $\begin{array}{c}\text { Coefficient } \\
\text { of variation }\end{array}$ & $\mathrm{n}$ & Strain 12 & $\begin{array}{c}\text { Coefficient } \\
\text { of variation }\end{array}$ & $\mathrm{n}$ \\
\hline 8 & $8.7 \pm 1.9$ & 21 & 10 & $11.0 \pm 2.1$ & 19 & 5 \\
10 & $8.0 \pm 0.8$ & 10 & 12 & $14.5 \pm 2.7$ & 19 & 8 \\
12 & $14.8 \pm 3.8$ & 25 & 10 & $10.8 \pm 1.4$ & 13 & 9 \\
14 & $7.6 \pm 0.9$ & 12 & 8 & $15.9 \pm 4.2$ & 26 & 9 \\
16 & $18.0 \pm 2.8$ & 15 & 10 & $23.2 \pm 5.6$ & 24 & 10 \\
18 & $15.1 \pm 2.2$ & 15 & 10 & $15.6 \pm 7.3$ & 47 & 8 \\
20 & $6.4 \pm 1.0$ & 16 & 10 & $11.7 \pm 3.3$ & 28 & 10 \\
24 & $3.4 \pm 0.2$ & 6 & 10 & $5.6 \pm 1.4$ & 25 & 8 \\
28 & $10.0 \pm 3.7$ & 37 & 10 & $13.6 \pm 8.2$ & 60 & 9 \\
32 & $2.3 \pm 0.5$ & 22 & 10 & $6.2 \pm 1.2$ & 19 & 10 \\
& & & & & & 8 \\
\hline
\end{tabular}


thereafter in strain $\mathrm{O} 3$ rats. However, in strain 12 rats, the FSH concentrations increased from days 8 to 12 of age, then remained high until day 20 of age and decreased thereafter. Between 10 and 32 days of age, the concentrations of $\mathrm{FSH}$ were significantly higher in strain 12 than in strain $\mathrm{O} 3$ rats. It is noteworthy that in the two strains of rats, the concentration of FSH decreased at the moment when the antral follicles appeared.

(ii) LH plasma concentrations. - In both strains the LH concentrations were neither correlated with age nor with the development of the follicular population (table 2). The coefficient of variation was higher in strain 12 than in strain $O 3$ rats between 14 and 28 days of age and no difference can be detected between strains.

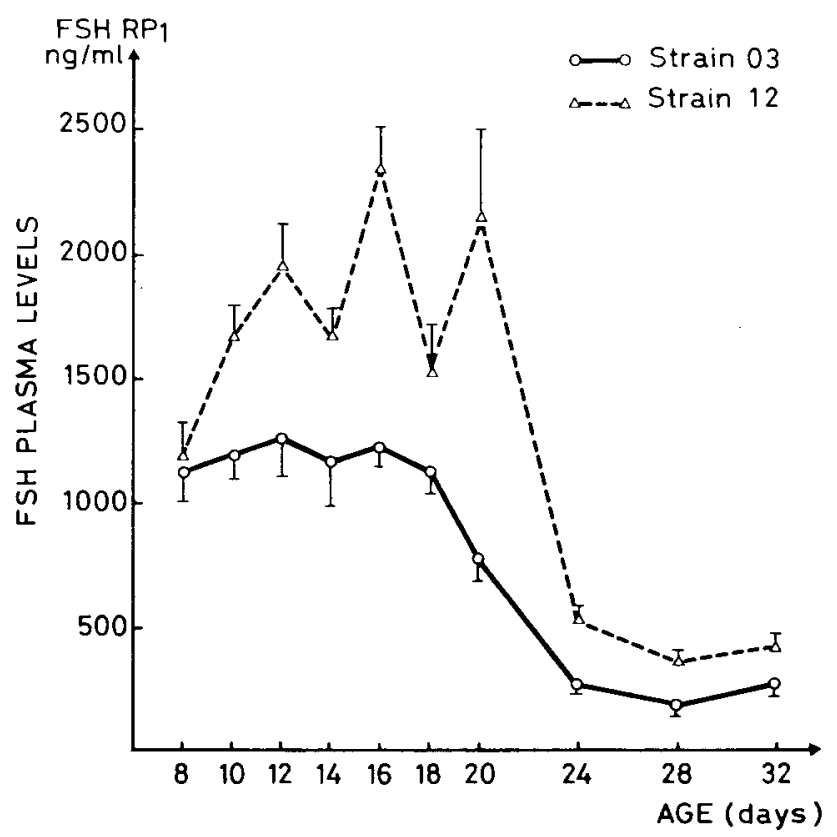

FIG. 4. - Comparison of the FSH plasmalevels in female rats between 8 and 32 days of age (strains $\mathrm{O} 3$ and 12).

\section{Discussion.}

Evolution of the follicular population.

The number of follicles at a given stage in an ovary at a given time depends on three parameters : (i) the rate follicles leave the reserve of primordial follicles and enter the growth phase, (ii) the growth rate of follicles in the growth phase and (iii) the rate of atresia of growing follicles. These three parameters vary. with the age of the animal and are perhaps not independent.

The present study has shown the progressive evolution of the follicular population during the immature period and only after 20 days of age were antral follicles clearly visible in the rat which is similar to that found in the mouse (Pedersen, 1969). At 20 days of age in both the rat and the mouse, the number of growing follicles reaches 
a maximum due mainly to the rate at which follicles enter and grow throughout the growth phase, as at this time the rate of atresia is very low. This supports the results of Pedersen (1969) in the mouse and Hage et al. (1978) in the rat, that show that follicle growth initiation and follicular growth rates are high in the first two weeks of life. At 32-35 days of age in both the rat and the mouse, the number of growing follicles is reduced due to an increase in atresia and a decrease in the rate follicles enter the growth phase.

Our quantitative study of the follicular population in two strains of rats confirms the work of Peters (1969) in the mouse suggesting a constructive phase followed by a regressive phase. However it is interesting to consider the factors that influence the evolution of the follicular population because although large differences initially appear in this evolution (between 12 and 20 days of age), the final populations are similar in both strains at 32 days of age which is just prior to puberty.

One of us (Mauléon, 1978) has compared the rates of initiation of follicular growth in rats of both strains, between 7 and 25 days of age by counting the dormant follicles (i.e. with less than $26 \pm 6$ follicle cells) and those having commenced growth (i.e. follicles with some round follicular cells, large oocytes and the nucleus of the oocyte larger than $9.7 \mu \mathrm{m}$ in diameter but an area less than $1259 \mu \mathrm{m}^{2}$. The results summarized in table 3 show that in strain 12 rats, follicles initiate growth at a slower rate, than in strain $\mathrm{O} 3$ rats.

TABLE 3

The rate of initiation of follicular growth in two strains of rats at 7 and 25 days of age (After Mauléon, 1978)

\begin{tabular}{ccccccc}
\hline $\begin{array}{c}\text { Age } \\
\text { of rats } \\
\text { Strain }\end{array}$ & $\begin{array}{c}\text { Dormant } \\
\text { primordial } \\
\text { follicles }\end{array}$ & $\begin{array}{c}\text { Growing } \\
\text { primordial } \\
\text { follicles }\end{array}$ & $\begin{array}{c}\text { Rate of } \\
\text { initiation } \\
(p .100)\end{array}$ & $\begin{array}{c}\text { Dormant } \\
\text { primordial } \\
\text { follicles }\end{array}$ & $\begin{array}{c}\text { Growing } \\
\text { primordial } \\
\text { follicles }\end{array}$ & $\begin{array}{c}\text { Rate of } \\
\text { (p. 100) }\end{array}$ \\
\hline
\end{tabular}

03

12
$8200.1+628.7 \quad 1041.1+194.4$

(11)

$9391.8 \pm 368.3$

(9)
$(11)$

$578.1 \pm 57.3$

(9)
12,6

6.1
$5689.0 \pm 185.2$

(25)

$6125.7 \pm 463.3 \quad 191,1 \pm 28.5$

(10)
8.1

3.1

In the present study the relative proportion of atresia after day 20 , when there are significant levels of atresia, are the same as, or even slightly higher in strain 12 compared to strain $\mathrm{O} 3$ rats (table 1 ).

And since (i) initiation of follicle growth is at a lower level, (ii) the rate of atresia is the same or higher in strain 12 rats and (iii) at 32 days of age both strains have the same number of follicles, then it is probable that the follicular growth rate is higher in strain 12 than in strain $\mathrm{O} 3$ rats. However this more rapid growth in strain 12 rats is likely to occur after 20 days of age since antral follicles first appear in strain $\mathrm{O} 3$ rats at 20 days of age and at 24 days of age in strain 12 rats.

Therefore we suggest that a difference exists between these two strains principally in the rate follicles initiate growth and that the other factors like rate of atresia and growth are modified as a consequence of this primary difference. 
Hormonal concentrations and follicular development.

Measurable levels of FSH and LH are present in the pituitary very early in life (Corbin and Daniels, 1967) and reach a maximum respectively in both strains of rats at 20 and 24 days of age (de Reviers and Terqui, 1976).

The general evolution in FSH plasma levels found in the present study show a high concentration between 8 and 18 days of age and a low concentration between 24 and 32 days. By contrast any possible evolution in the plasma concentrations of LH remains undefined due to the large individual variations. Comparable results have been found by numerous other authors (Ojeda and Ramirez, 1972 ; Meijs-Roelofs et al., 1973 ; and others).

The relationship between the concentration of FSH and follicular development is evident with the hormonal events preceeding the follicular events (e.g. the maximum concentration is reached before the maximum number of follicles is attained; the fall in FSH concentration preceeds the fall in the number of follicles). However when the antral follicles begin to form, FSH concentrations fall which is probably due to the appearance of the feedback effects of œstrogens and " inhibin-like » factors present in the follicular fluid.

Comparison in the evolution of FSH and the follicular population shows clearly that the poorer follicular development in the strain 12 rats is not due to a lack of FSH. It has been shown that the concentration of FSH prior to 20 days of age is necessary for the development of a large number of follicles and reduction of FSH during this period by treatments with steroids or anti-FSH antiserum reduces the number of medium sized follicles and especially the number of antral follicles (Uilenbroek ef al., 1976).

Our results unexpectedly show that a high level of FSH results in a low number of follicles. Such a result has two possible explanations :

(i) perhaps an anti-gonadotrophic factor is present in the early prepubertal period in strain 12 rais-such a factor has been suggested by Thieblot ef al., 1966. However this hypothesis does not explain the observed difference in ovarian response to exogenous gonadotrophin in the adult (Mariana ef al., 1973) and in the young (Land ef al., 1974).

(ii) perhaps the more plausible explanation is there is a strain difference in the acquisition of FSH receptors. FSH has been shown to act very early in follicular development both in vitro (Ryle, 1972) and in vivo (de Reviers and Mauléon, 1973). Furthermore, Presl et al. (1974) have found FSH receptors on follicles with only two layers of granulosa cells. The acquisition of FSH receptors on small follicles may occur later or in fewer follicles in strain 12 rats.

This would agree with the observations that the rate follicles initiate growth is lower and the ovarian response to exogenous FSH in both the young and adult is lower in strain 12 than in strain $\mathrm{O} 3$ rats. The poorer ovarian response to exogenous gonadotrophins thus could be either due to a poorer receptivity to $\mathrm{FSH}$ which persists in the animals adult life or that all the follicles able to be stimulated develop their receptors at one time in the immature animals. In the later case the follicles that are 
able to be stimulated are programmed at a very early stage in life which could explain the heterogeneity in the population of primordial follicles (Mariana, 1978).

Reçu en ovril 1979.

Accepté en mai 1979.

Acknowledgments. - The authors are greatly indebted to Dr. L. P. Cahill for translating and commenting the manuscript and to Dr. R. B. Land for his valuable criticism. They are thankful to the NIAMDD for the gift of materials used for radioimmunoassays of rat FSH and LH.

Résumé. Une analyse histologique quantitative de la population des follicules ovariens en croissance a été effectuée dans deux souches de rats Wistar (03 et 12) au cours de la période prépubère (8-32 jours post-natal). Les deux souches diffèrent par leur sensibilité ovarienne à FSH exogène durant cette période : $03>12$. Cette analyse montre une phase où le nombre total de follicules en croissance augmente ( 8 à 20 jours) et une phase où ce nombre décroît (20 à 32 jours). Cette diminution résulte d'une forte atrésie, mais aussi d'un nombre plus faible de follicules entrant en croissance. Chez les rattes de la souche 12 , le développement folliculaire est plus faible (nombre et taille) que dans ceux de la souche 03 , à 12 et 20 jours post-natal, mais la population folliculaire est comparable à 32 jours.

Les niveaux plasmatiques de LH mesurés entre 8 et 32 jours post-natal n'apparaissent pas différents entre les deux souches, mais présentent une grande variabilité. Par contre, les niveaux plasmatiques de FSH sont significativement plus élevés chez les animaux de la souche 12.

Ce fait est surprenant puisque FSH agit sur la croissance folliculaire et que la population folliculaire de l'ovaire de la souche 12 est faiblement développée. Un moindre développement des récepteurs à FSH à un stade très précoce de la croissance du follicule dans l'ovaire de ces animaux serait une hypothèse plausible.

\section{References}

BEAUMONT H. M., MANDL A. M., 1962. A quantitative and cytological study of oogonia and oocytes in the fotal and neonatal rat. Proc. roy. Soc. $B, 155,557-579$.

CHALKLEY H. W., 1943. Method for the quantitative morphologic analysis of tissues. J. nat. Cancer Inst., 4, 47-53.

CORBIN A., DANIELS E. L., 1967. Changes in concentration of female rat pituitary FSH and stalkmedian eminence follicle stimulating hormone releasing factor with age. Neuroendocrinology, 2, 304-314.

HAGE A. J., GROEN-KLEVANT A. C., WELSCHEN R., 1978. Follicle growth in the immature rat ovary. Acia. endocr., 88, 375-382.

LAND R. B., de REVIERS M. M., THOMPSON R., MAULÉON P., 1974. Quantitative physiological studies of genetic variation in the ovarian activity of the rat. J. Reprod. Fert., 38, 29-39.

LANE R., 1935. The follicular apparatus of the ovary of the immature rat and some of the factors which influence it. Anat. Rec., 61, 141-153.

LINTERN-MOORE S., 1977. Initiation of follicular growth in the infant mouse ovary by exogenous gonadotrophin. Biol. Reprod., 17, 635-639.

MANDL A. M., ZUCKERMAN S., 1950. The numbers of normal and atretic ova in the mature rat. J. Endocr., 6, 426-435.

MARIANA J. C., 1978. Analyse biométrique de l'index de marquage des cellules folliculeuses et de la taille des ovocytes des follicules primordiaux d'ovaire de ratte adulte cyclique. Ann. Biol. onim. Bioch. Biophys.,18, 1333-1342. 
MARIANA J. C., de REVIERS M. M., MAULÉON P., 1973. Some endocrine parameters in three lines of rats. In PETERS H., The development and maturation of the ovary and its functions. Excerpta. med. I. C. S., 267, 24-28.

MAULEON P., 1978. Ovarian development in young mammals, 141-158. In CRIGHTON D. B., HAYNES N. B., FOXCROFT G. R., LAMING G. E. Control of ovulation, Butterworths Lond.

MAULÉON P., HANUMANTHA RAO K., 1963. Variations génétiques des populations folliculaires dans les ovaires de rates impubères. Ann. Biol. anim. Bioch. Biophys., 3, 21-31.

MEIJS-ROELOFS H. M. A., UILENBROEK J. Th. J., OSMAN P., WELSCHEN R., 1973. Serum Jevels of gonadotropins and follicular growth in prepuberal rats. In PETERS H., The development and maturation of the ovary and its functions. Excerpta. med. I. C. S. 267, 3-11.

OJEDA S. R., RAMIREZ V. D., 1972. Plasma levels of LH and FSH in maturing rats : response to hemigonadectomy. Endocrinology, 90, 466-472.

PAESI F. J. A., 1949. The relation between the rate of growth of the ovarian follicles and the shape of the frequency curve representing their variability in size. Acta endocr., 3, 173-180.

PEDERSEN T., 1969. Follicle growth in the immature mouse ovary. Acta endocr., 62, 117-132.

PEDERSEN T., PETERS H., 1968. Proposal for a classification of oocytes and follicles in the mouse ovary. J. Reprod. Fert., 17, 555-557.

PETERS H., 1969. The development of the mouse ovary from birth to maturity. Acta endocr., 62, 98-116.

PRESL J., POSPISIL J., FIGAROVA V., KRABEC Z., 1974. Stage-dependent changes in binding of iodinated FSH during ovarian follicle maturation in rats. Endocrinol. Exp., 8, 291-298.

REVIERS M. M. de, MAULÉON P., 1973. Effet des hormones gonadotropes sur l'ovaire de ratte immature. Ann. Biol. anim. Bioch. Biophys., Suppl. 13, 177-193.

REVIERS M. M. de, TERQUI M., 1976. Ovarian follicular development and gonadotrophin levels during prepubertal life in three strains of rat with different sensitivity to FSH. Ann. Biol. anim. Bioch. Biophys., 16, 307-311.

RYLE M., 1972. The growth in vitro of mouse ovarian follicles of different sizes in response to purified gonadotrophins. J. Reprod. Fert., 30, 395-405.

THIEBLOT L., BERTHELAY J., BLAISE S., 1966. Isolement d'un principe antigonadotrope dans l'urine d'enfants impubères. C. R. Soc. Biol., 160, 1871-1874.

UILENBROEK J. Th. J., ARENDSEN de WOLFF-EXALTO E., WELSCHEN R., 1976. Studies on the significance of the high levels of follicle-stimulating hormone for follicular development in immature rats. Ann. Biol. anim. Bioch. Biophys., 16, 297-305.

UMEZU M., 1970. The basal observation of puberty in female rats. The changes in weight of ovaries and uterus and the development of ovarian follicles. Jap. J. Anim. Reprod., 16, 71-76. 